Windle, J. and Briggs, D. (2015). 'Goin Solo: The Social Organisation of Drug Dealers within a London Gang'. Journal of Youth Studies, 18(9): 1170-1185 Pre-publication copy

\title{
Going Solo: The Social Organisation of Drug Dealing within a \\ London Street Gang
}

\author{
James Windle and Daniel Briggs ${ }^{1}$
}

\begin{abstract}
This paper presents a single case study of one street gang in one London borough. Semistructured interviews were conducted with 12 gang members, or former gang members, and seven practitioners. The practitioners and gang members / ex-gang members reported different perspectives on how the gang was structured and drug dealing was organised. The gang members / ex-gang members suggested that the gang is a loose social network with little recognisable formal organisation. Although individual gang members sell drugs, the gang should not be viewed as a drug dealing organisation. Rather it is a composition of individual drug dealers who cooperate out of mutual self-interest. Therefore, some gang members are best described as independent entrepreneurs while others are subcontractors looking to 'go solo'. The seven practitioners, however, tended to describe a more hierarchically structured gang, with formal recruitment processes. This divergence of perspective highlights an important consideration for policy and research.
\end{abstract}

\footnotetext{
${ }^{1}$ School of Business and Law, University of East London, University Square, Stratford, London, UK; Criminology, Facultad de Ciencias Sociales, Universidad Europea, Madrid, Spain. Corresponding author: J.Windle@uel.ac.uk
} 
Windle, J. and Briggs, D. (2015). 'Goin Solo: The Social Organisation of Drug Dealers within a London Gang'. Journal of Youth Studies, 18(9): 1170-1185 Pre-publication copy

\section{Going Solo: The Social Organisation of Drug Dealing within a London Street Gang}

In recent years, political and social concern has increased around the proliferation of street gangs $^{2}$ in the UK. David Cameron, the British Prime Minister, has described them as:

Territorial, hierarchical and incredibly violent ... mostly composed of young boys... They earn money through crime, particularly drugs, and are bound together by an imposed loyalty to an authoritarian gang leader (cited in Wintour et al. 2011).

There is, however, a lack of empirical research on how gangs are structured, and their role in drug distribution in the British context (Alleyne and Wood 2010; Ralphs et al. 2009).

This paper is based upon a time-limited, exploratory study conducted over seven months in 2012/2013. During this period we interviewed 12 gang members and former gang members, and seven practitioners in one London borough (Rose Borough) with, what might be termed, an emerging gang problem (see Decker and Curry 2002; Fox and Lane 2010). The research objectives were to investigate how the boroughs gangs were structured, and how the gangs organised drug dealing. The findings are presented here in the form of a case study of one of the boroughs gangs: Red Gang. ${ }^{3}$

\footnotetext{
${ }^{2}$ This paper takes as a starting point the Eurogang definition of a street gang as a 'durable and street orientated youth groups whose involvement in illegal activity is part of their group identity' (Klein et al., 2006. p. 414). We do, however, acknowledge that the term street gang is highly contested. For in-depth definitional debates please refer to Joseph and Gunter (2011), Smithson and colleagues (2012) and, Wood and Alleyne (2010). This papers reviewers questioned whether Red Gang should be labelled a gang. We acknowledge the ambiguity of the term, and the dangers of labelling a group a gang (see Klein 1995; Smithson et al., 2012), however, as the young people and practitioners we interviewed identified the group as a gang we chose to employ the term. Furthermore, Red Gang had lasted for more than a couple of months (i.e. is durable), hung around in public places (i.e. is street orientated) and members were involved in a range of illegal activities, including a 'beef' resulting in two murders. Red Gang thus conforms to the basic Eurogang criteria (see Weerman et al. 2009),

${ }^{3}$ All names and locations have been anomyzed to reduce potential stigmatization of the research site and protect participants (see Aldridge and Medina 2008; May et al. 2005).
} 
Windle, J. and Briggs, D. (2015). 'Goin Solo: The Social Organisation of Drug Dealers within a London Gang'. Journal of Youth Studies, 18(9): 1170-1185 Pre-publication copy

While many British researchers have been reticent of drawing too many parallels between British and American gang experiences, recent studies have highlighted some similarities (Klein et al. 2006). As such, the next section will summarise American research on gang structures. This will be followed by a summary of the less extensive British gang research. The paper will then discuss the structure of Red Gang, followed by how members entered the gang. The concluding section draws together the discussion on structure by examining the organisation of drug dealing within Red Gang.

\section{Gang structures: The American literature}

There has been a significant amount of debate in America about whether gangs are (see Curry et al. 2013):

1. Hierarchical, bureaucratic, organisations with formal rules and procedures, strict divisions of labour and central budgets which all must contribute to. In this type of structure influence and control flow from the top; or;

2. Looser social networks of individuals connected through informal relationships in which individuals and small cliques cooperate out of mutual self-interest. In this type of structure influence and control 'go up and sideways as well as down' (March and Simon, 1993, p. 6).

Martìn Sánchez-Jankowski (1991, p. 100, also 2003) rejects the identification of gangs as loose social networks as 'simply not accurate':

... gangs are more than loose temporary associations. They are collectives in which the interaction of individuals, both leadership and rank and file, is organized and governed by a set of rules and roles (Sánchez-Jankowski 1991, p. 314, see also Padilla 1996; Ruble and Turner 2000).

Sudhir Venkatesh (1997, see also Venkatesh and Levitt 2000) presents a case study of a hierarchical gang: the Black Kings of Chicago. The Black Kings had well defined leaders, held regular meetings and controlled a percentage of profits from the illicit activities of its members. Some factions kept written accounts of their financial accounts, the leadership 
Windle, J. and Briggs, D. (2015). 'Goin Solo: The Social Organisation of Drug Dealers within a London Gang'. Journal of Youth Studies, 18(9): 1170-1185 Pre-publication copy

possessed significant authority over its members, and gang members tended to have shared values (see also Skolnick et al. 1990).

Thomas Mieczkowski (1986, p. 659) similarly refers to smaller cliques of drug dealers within larger gangs as hierarchically structured. All gang members studied by Mieczkowski had well-defined roles, and more established gang members 'were expected to actively manage the team effort of runners, much as any entrepreneurial business required management'. Felix Padilla (1996) similarly described sanctions being enforced against individuals who ran scams without the authorisation of the gang leadership.

G. David Curry and colleagues (2013), however, suggest that hierarchically structured gangs are rare and that looser social networks are more commonplace. The corresponding literature suggests this is the case (see Decker 2000; Decker et al. 1998; Decker and Van Winkle 1994; Durán 2010; Esbensen and Huizinga 1993; Esbensen and Tusinski 2007; Fagan 1989; Weisel 2002). For example, two studies of gangs in St Louis found that gangs lacked leadership, well-defined roles or internal discipline and little, if any, proceeds from individual enterprises made its way to a central budget. This is evident in the gang's inability to effectively organise coordinated drug sales (Decker and Van Winkle 1994; see also Esbensen and Huizinga 1993) or homicides against people from other gangs (Decker and Curry 2002).

Moreover, many gangs that appear to be hierarchically structured can, upon further inspection, be looser networks. Scott Decker and colleagues (1998), for example, found that while the Gangster Disciples were bureaucratic in much of their activities, especially in violent conflicts, in terms of drug sales there was little organisation, with few surrendering profits to gang budgets. This lack of coordination may simply reflect individual gang member's aversion to being bound by formal rules imposed by others (Decker 2000), and the general 'preference for autonomy' exhibited by many drug dealers (Fairlie 2002, p. 526): an activity favoured by many, but by no means all, gang members (Curry et al. 2013; Marshall et al. 2005; Pitts 2008).

\section{Gang structures: The British literature}

There is a visible split in the British literature between studies conducted in London and cities in the north of England. Studies of London gangs by John Pitts $(2007,2008)$ and James Densley (2012, also Densley and Stevens, 2014) describe hierarchically structured groups 
Windle, J. and Briggs, D. (2015). 'Goin Solo: The Social Organisation of Drug Dealers within a London Gang'. Journal of Youth Studies, 18(9): 1170-1185 Pre-publication copy

(see also Harding, 2014). Pitts (2008, p. 70) portrays authority flowing down from established organised crime figures ('faces'), to 'elders', 'youngers', 'tinies', 'wannabe's' and 'shotters' (also Centre for Social Justice 2009). For Pitts, the faces work behind the scenes to provide the protective function of violent reputations whilst wholesaling drugs to elders (see also Lo 2011). The elders were in their late teens / early twenties and led 'crews' of youngers (aged 14-17) who acted as 'foot soldiers'; ${ }^{4}$ running drugs, collecting debts and attacking rivals. Wannabes and tinies were then exploited to engage in even higher risk, lower valued work. While the Centre for Social Justice (2009, p. 81) calls this type of gang 'semiorganised', Densely (2012) suggests such structured gangs may be closer to organized crime groups than gangs: as might the groups described by Mieczkowski, Sánchez-Jankowski and Venkatesh. This said, much of the organised crime literature disputes the common held perception of all, or even most, organised crime being hierarchically structured (Hobbs 2013; Morselli 2001; Reuter 1983; Windle 2013).

A number of studies of gangs in the North of England identified loose social networks. Judith Aldridge and Juanjo Medina (2008, p. 17) observed gangs as 'fluid, loose, messy and interlinked networks', more like 'friendship networks than formal organisations'. Leadership 'was generally unstable, shifting and shared' (see also Bullock and Tilley 2002, 2008; Mares 2001). Hannah Smithson and colleagues (2012, p. 63) similarly suggested that of the gangs they observed the:

... vast majority [of participants] felt strongly that their group was not organized, had no structure and was simply a group of friends doing what they choose to do.

This said, a number of participants spoke of leaders in some, but not all, groups when discussing beefs (violent conflicts) and, bosses in terms of individual drug dealing relationships (Smithson et al. 2012).

In summary, structures vary. They are dependent upon, and adapt to, the environment upon which they operate and the personalities of their members (Curtis and Wendel 2000; Hobbs 2013; Pitts 2008; Sánchez-Jankowski 1991). Structural changes may even represent an

\footnotetext{
${ }^{4}$ Note how the use of language implies a group organised in a similar fashion to the most bureaucratic of institution: the military.
} 
Windle, J. and Briggs, D. (2015). 'Goin Solo: The Social Organisation of Drug Dealers within a London Gang'. Journal of Youth Studies, 18(9): 1170-1185 Pre-publication copy

adaptive response to counter-measures (see Kenney 2007; Windle and Farrell 2012). As such it may be best to view gang structures on a continuum from the less organized to the more organized (see Curry et al. 2013; Decker et al. 1998), and from the more recreational to the more entrepreneurial (Densley 2012). The evidence presented below suggests that the gang members / ex-gang members we interviewed experienced their gang as not particularly well organized but fairly entrepreneurial; or at least some individuals are entrepreneurial. The practitioners we interviewed, conversely, identified a more sophisticated entrepreneurial organisation which closely resembled the gangs investigated by Pitts.

\section{Methodology}

We conducted 12 open-ended interviews with young people who identified themselves, or had been identified as, gang members or former gang members of one of Rose Boroughs six gangs. All were attending Rose Boroughs Youth Offending Team (YOT). ${ }^{5}$ The research took place from June 2012 to January 2013. Access and interview rooms were facilitated by Rose Borough YOT. Ethical clearance was provided by the University of East London Research Ethics Committee. Questions were specifically designed around eliciting information about the drug dealing activities and organisation of gangs in Rose Borough. Interviews lasted an average of 45 minutes.

Participants were aged between 12 and 18 and mostly of minority ethnic background $(n=10)$, although two were white English $(n=2)$. All but one of the participants was male and either a member or former member of Red Gang. ${ }^{6}$ One female participant was a member of another Rose Boroughs gang. All of these young people had been excluded from secondary school and had attended or were attending alternative educational sites where similar other 'problematic students' were attending. That the majority of participants were from Red Gang is representative of the number of Red Gang members attending YOT.

\footnotetext{
${ }^{5}$ While some of the participants initially claimed to not be gang members, as the interviews progressed many began to imply or openly state gang membership. In one case, a participant repeatedly asserted that he was not a gang member, yet presented from his pocket a bandana showing his gangs colours.

${ }^{6}$ This said, two of the participants identified as members of Red Gang were younger than the stated age range of Red Gang. They may, therefore, have been members of FDB, a younger gang connected to Red Gang in a loose coalition, or they may have been popular enough to be allowed to hang with Red Gang.
} 
Windle, J. and Briggs, D. (2015). 'Goin Solo: The Social Organisation of Drug Dealers within a London Gang'. Journal of Youth Studies, 18(9): 1170-1185 Pre-publication copy

We also interviewed six practitioners who worked in the Rose Borough YOT (four Youth Offending Officers and two senior managers working within the YOT) and one Metropolitan Police officer. These professionals had worked extensively with our sample and with numerous other young people from the area. They had a solid knowledge of the social pressures which these young people were exposed, the kind of situations that had led to their YOT attendance and the operations of local drug markets.

The finite time period of the research provided several limitations. First, we were limited to gang members who were attending the Rose Borough YOT, and given the authoritative setting, it was difficult for some to feel totally comfortable about disclosing potentially sensitive information. We do not doubt the formalised setting of the YOT affected our data collection, however, we tried to overcome this by using established interviewing techniques, presenting ourselves as neutral to the YOT as well as impartial to their daily lives: as someone who would not judge them on their activities. Second, our sample was limited to those who had been processed through the youth justice system and excluded individuals from the older Rose Town-based gangs. We acknowledge that the older gang members may have provided yet another perspective on how Red Gang was structured and their relationship with other gangs in the area. Third, it may be argued that the lack of numbers limits generalisation. This was not, however, the aim of this paper. The aim was to identify the structure and drug dealing operations of one gang in one London borough. The participants, while small in number, represent a large sample of the population of one gang in a four gang coalition. Such single case studies are important and provide opportunities for comparison with other single case studies. The next section will provide some context by introducing the borough and the gang under investigation.

\section{Introducing Red Borough and Red Gang}

To facilitate discussion on the structure and organisation of drug dealing this section will briefly introduce Red Gang and their area. Rose Borough is one of London's most economically deprived areas. It has one the capitals highest proportion of children living in low income families (London Poverty Profile 2013). Between July 2009 and June 2010, 13.2 percent of the boroughs population were unemployed; compared to the London average of 9 percent, and UK average of 7.9 percent (Office of National Statistics 2013). 
Windle, J. and Briggs, D. (2015). 'Goin Solo: The Social Organisation of Drug Dealers within a London Gang'. Journal of Youth Studies, 18(9): 1170-1185 Pre-publication copy

We were told by Rose Borough YOT that there were 12 gangs and peer groups operating within the borough. This study focuses upon one gang: Red Gang. There was, however, much confusion over what constituted Red Gang. While all participants identified with Red Gang many participants used the name interchangeably to mean:

1. A coalition of four gangs based in Rose Town (a district of Rose Borough): GBH, Rose Boys, Red Gang and FDB;

2. Red Gang (a single gang).

One participant suggested that GBH, Rose Boys, Red Gang and FDB are 'basically the same gang', which is why they all carry a red bandana. Most practitioners similarly described Red Gang as one gang with different tiers based loosely on age groups: GBH at the top, followed by Rose Boys, Red Gang and FDB at the bottom. Two participants, however, described little routine interaction between the Rose Town-based gangs:

Like GBH will chill in one spot and Red Gang will chill in one spot, and they [Rose Boys] will chill in another spot. So they don't really see each other (Maxwell).

Furthermore, Red Gang and GBH are in conflict. Or at least individual gang members are in conflict. The conflict appears to centre upon members of Red Gang buying drugs direct from a wholesaler from another part of London. This seems to have disrupted pre-existing agreements because, prior to this, members of GBH were the primary wholesale suppliers to the area. When this rift occurred, our participants suggest that GBH felt aggrieved that Red Gang had cut them from the distribution chain and began robbing drug dealers connected to Red Gang, resulting in a number of stabbings. This said, participants agreed that all four gangs unite to achieve common objectives, especially involvement in disputes with other gangs (see Windle and Briggs forthcoming). ${ }^{7}$

\footnotetext{
7 The Rose Town-based gangs are engaged in an ongoing conflict with a gang from a neighbouring borough. The conflict escalated after a core member of one of the primary Rose Town-based gangs was murdered. Participants, and one practitioner, suggest that 'beefs' are seldom overtly about drug territory, but rather reputation (see Aldridge and Medina 2008; Klein et al. 2006). This does not mean that reputation and business
} 
Windle, J. and Briggs, D. (2015). 'Goin Solo: The Social Organisation of Drug Dealers within a London Gang'. Journal of Youth Studies, 18(9): 1170-1185 Pre-publication copy

To avoid confusion, the remainder of this paper will refer to Red Gang as the individual gang. The coalition of four gangs will be referred to as the Rose Town-based gangs.

There were several estimates of how many individuals are in the core/fringe ${ }^{8}$ cohort of the Rose Town-based gangs. While most agreed on a core of between 15 and 20 per gang, estimates went as high as 70; possibly representing a combination of all four gangs. Maxwell, however, suggested that a core of 15/16 Red Gang members could be increased by calling for the backup of 60/70 individuals on the fringe of the gang; Richard claimed the fringe to be closer to 150 individuals. The fact that our participants cannot agree on precise numbers may be representative of the fluidity of the gang. The following section details how Red Gang is structured.

\section{Structure}

The gang members / ex-gang members participating in this study presented Red Gang as a loose social network, rather than a hierarchical organisation. Most of the narratives indicated desires to retain individuality and avoid being bossed around. There was no indication of a central bureaucracy or budget, and no clear division of labour. In fact, none of the participants were able to clearly articulate the structure of Red Gang; except to pinpoint potential 'leaders'. This said, it appears that even those with greater authority do not make formal decisions which all must obey. Rather Red Gang appears to be a loose network of individuals 'engaged in reciprocal, preferential, mutually supportive actions' (Powell 1990, p. 303) which is characterised more by cooperation than organisation (Morselli 2001). Two of the participants went as far as to describe Red Gang as nothing more than a group of 'friends', who just 'chill' and occasionally co-offend. That is, like many gang members, they

interests are not related. As signs of perceived weakness may be seen as an invitation to competitors (Hobbs 2013; Winlow 2001; Windle 2013) the development of a violent reputation may be instrumental in reducing the encroachment of competitors (see Bourgois 1995; Gambetta, 1993; Windle 2013). This is not to suggest that all violence confirms to norms of economic rational choice, but rather there is a convergence of commercial and personal interests (Hobbs 2013; see Davies 1998).

${ }^{8}$ While relationships are more complex than the core/fringe distinction implies (Papachristos 2006), it does represent a useful starting point. 
Windle, J. and Briggs, D. (2015). 'Goin Solo: The Social Organisation of Drug Dealers within a London Gang'. Journal of Youth Studies, 18(9): 1170-1185 Pre-publication copy

spend more time socialising than engaging in criminal activities (Klein 1995; also Aldridge and Medina 2008).

Jermaine named the leader of Red Gang as Lethal, while Kane suggested that there is one 'big guy' who directs all four Rose Town-based gangs, named by Dylan as Riko. According to Kane apart from the 'big guy [Riko] ... everyone else is the same'. Kwasi went further to state that older gang members 'do not manage things' and, while they must be respected, their demands can be refused. While influential, Lethal and Riko do not seem to exert absolute control over Red Gang, or the four gang coalition, and people can, and do, dispute their instruction. This, however, probably depends largely on individual relationships. For example, Kwasi was one of the older participants. He was physically imposing and appeared fairly confident. These attributes may have placed him in a strong position to dispute the instruction of more established members.

For many gangs, leadership - where there is some - is often 'more a function of individual prowess and reputation than a formalized structure for making collective decisions' (Weisel 2002, p. 41; also Aldridge and Medina 2008; Fagan 1989). That is, leaders do not lobby members for their votes in a democratic process, nor are their rights and obligations formalised in a constitution. Rather, as in other social groups, those with certain desirable attributes come to take the lead. Some, such as Kwasi, may possess attributes which allow them to dispute instructions of more influential members, referred to, or perceived, as leaders.

The older/younger distinction appears to be less pronounced than identified by Pitts (2007, 2008). It appears that moving up from younger to older within Red Gang is less about age and more to do with individual popularity, if such a distinction exists at all:

Dylan: I think it goes not just by age but by how certified you are. You know what I mean, like how good you are ennit, if you know what I mean.

Like how much ratings you got, if you're rated

Q: What would you do to increase your rating?

Dylan: Well just like if people like you more. If these people like you and that. 
Windle, J. and Briggs, D. (2015). 'Goin Solo: The Social Organisation of Drug Dealers within a London Gang'. Journal of Youth Studies, 18(9): 1170-1185 Pre-publication copy

This does appear to conflict somewhat with the views of practitioners who tended to identify a clear hierarchy, based upon age. They suggested that GBH (aged 21-25) sat at home giving orders to Rose Boys (19-23) and Red Gang (aged 14-18), who, in turn, supervise FDB in their drug selling. This is opposed to the statements of most young people who saw Red Gang as separate from GBH and Rose Boys.

Echoing Pitts description of gang structures, YOT workers (and one gang affiliate) we interviewed spoke in terms of foot soldiers and managers. One YOT worker described GBH as:

They're staying at home. They're not kind of committing violence. They're not front line, and therefore their just kind of sitting back.

An indication of the perceived level of organisation was given by another YOT worker who recalls one young person being given a prime drug dealing territory as a reward for protecting older gang members from prosecution. While one former gang members suggested that being independent was a major reason for wanting to leave and distancing himself from Red Gang. This may suggest a perception of lost independence and of an imposing leadership and/or gang rules. Again, this may be connected to the gang members relationships with others, rather than rigid gang rules.

The picture painted by the participants is unclear. It appears that there may be both 'older's'/'younger's' in each of the individual Rose Town-based gangs, and an 'older'/'younger' distinction between the gangs. It seems, however, that these distinctions are fluid and dependent upon relationships between individuals rather than rigid gang rules. While there may appear from the outside to be some solid bonds between these young people, they may be more fragile than expected. This is true of all social networks which rely on interactions between individuals, and smaller cliques. The following sections delve further into Red Gang's structure by investigating how members entered into Red Gang and gang members' involvement in drug dealing.

\section{Entry into the gang}

Our participants described two perspectives on how people entered into Red Gang: 
Windle, J. and Briggs, D. (2015). 'Goin Solo: The Social Organisation of Drug Dealers within a London Gang'. Journal of Youth Studies, 18(9): 1170-1185 Pre-publication copy

1. Well organised, formal recruitment, often through peer influence, of potentially vulnerable individuals who may be excluded from mainstream school or attending Pupil Referral Units (PRU's) (see Briggs, 2010). This was the primary response of practitioners.

2. Individuals drift into their respective gangs because they are friendly with others connected to the gang (see Aldridge and Medina 2008; Fagan 1989): as you might drift into joining a local sports team, band or any other social group. This was the primary response of gang members / ex-gang members.

Four of the participants discussed how they met gang members whilst in school (see Akhtar and South 2000). Kwasi described how a small group of friends from school formed their own peer group which later collectively joined Red Gang:

... when you're young you go to school and you make friends with people in the area, you grow up with them. Then you just start making like they're probably 10 of you's and you just think to yourself let's make a gang. And then you get more people into it so it can get even bigger.

One other participant described recruitment at school as a socialised process:

I went to a school called Rose Park and there was a few Red Gang members there yeah, so I was just hanging about with them every day after school. I'll go to blocks and chill with them, smoke weed. Then from there it all started. Then I was just chilling with them more and more and more. Then I got involved with the police and that (Maxwell).

Dylan described knowing 'most of these boys since like before these gangs and that, like my Dad watched all of them grow up'. Another gang member did, however, suggest a more formal initiation process of 'beating in':

Kane: Yeah well it depends like, if someone comes and said they want to be in it like then everyone's got to earn their trust first. Then they get tested 
Windle, J. and Briggs, D. (2015). 'Goin Solo: The Social Organisation of Drug Dealers within a London Gang'. Journal of Youth Studies, 18(9): 1170-1185 Pre-publication copy

like beaten up and that to see if they're run from beef and stuff. See if they can handle it.

Q: Getting beaten up?

Kane: Yeah.

Q: By how many people.

Kane: Everyone that's there rushes them.

Q: And most people past this test do they? Are they asked to go to do robberies and stuff on people as another test?

Kane: Yeah they might say to you go punch them up, go rob them, go stab them whatever.

In some ways this supports Densley and Stevens (2014) findings that as co-offending requires an element of trust, few people enter gangs without having some prior relationship with an existing gang member. It may, therefore, be that those who do not have an existing relationship are 'beaten in' as a means of developing trust.

Responses to questions about entry into Red gang were ambiguous, which may suggest that membership of the gang is not clear-cut or collectively determined. This conflicts somewhat with practitioners who tended to see a more formal and calculated form of recruitment and exploitation in which older gang members cultivated relationships with children in, and through, schools. One practitioner described it as 'quite military in style', with gangs sending 'scouts' into schools to identify the most vulnerable.

\section{The structure and organisation of drug dealing}

Kwasi exemplifies the typical trajectory of our participants. He described in some detail how his drug dealing enterprise developed. He started selling cannabis on the street for someone else, waiting for passing trade in what would be described as an open drug market. ${ }^{9}$ This

\footnotetext{
${ }^{9}$ Open markets have fixed geographical locations and there are no barriers to entry. This will often involve dealers waiting in public areas for buyers to approach them. In a closed market purchases are only permitted if the dealer knows the buyer and has pre-arranged an agreed time and place (May and Hough 2004). While the introduction of cheap mobile phones in the late-1990s reduced the need for open selling (Lupton et al. 2002), such markets are still operational within London (Hales and Hobbes 2010; May et al. 2005).
} 
Windle, J. and Briggs, D. (2015). 'Goin Solo: The Social Organisation of Drug Dealers within a London Gang'. Journal of Youth Studies, 18(9): 1170-1185 Pre-publication copy

method is, according to Kwasi, often used by youths 'when they first start'. He quickly realised that selling in this way exposed him to greater threat of arrest and robbery. To reduce these risks he developed a closed market network of buyers who would phone him. He would then travel to drop-off points such as the buyer's home or car; never allowing a client to come to his home (see Lupton et al. 2002).

Joseph describes how he worked for others when he was young to save enough money to invest in his own drugs:

Joseph: I started by making moves for someone then it started from that.

Q: What just sat with them or were you kind of running to collect drugs for them. Did you just take the money, what was your role?

Joseph: Just tell them you want to sell it, then they'll give it to you and you sell it for them and pay them after. When you make enough money that's when you can start doing your own thing. Like buy it yourself and sell for yourself.

Both Joseph and Kwasi started working as subcontractors selling drugs for others. Not only did they accumulate savings which they invested in drugs to sell for themselves, but they also established trusting, reciprocal, relationships with dealers and clients (see Curry et al. 2013; Lampe and Johansen 2004; Valdez and Sifaneck 2004). ${ }^{10}$ They were operating as independent drug dealers, whilst simultaneously being part of Red Gang; membership of which provides - according to Kwasi - a protective function against robbery:

This said, none of the practitioners we spoke to were able to clearly identify any specific open drug markets. Two expressed suspicions that two separate open markets operated in car parks, and that Red Gang had recently started to discuss owning 'strips'.

${ }^{10}$ Participants may have also developed reputations for violence by robbing other drug dealers (see Briggs 2008, Harding, 2014; Hobbs 2013, Jacobs and Wright 2008; Windle 2013). A pursuit implied by several participants and practitioners. 
Windle, J. and Briggs, D. (2015). 'Goin Solo: The Social Organisation of Drug Dealers within a London Gang'. Journal of Youth Studies, 18(9): 1170-1185 Pre-publication copy

Yeah if people know that they sell drugs they'll just try to find you any time and rob you and you can't tell the police, obviously. So you've got to go and tell your boys and then someone can get killed. Stabbed. Shot (Kwasi).

The boroughs main drug markets seem to be centred around cannabis, and to a lesser extent cocaine, crack cocaine and heroin. As the local markets for heroin and crack are small, they are not popular drugs to sell within the borough. However, as crack cocaine sales are, according to one participant, worth double that of cannabis, most Red Gang members try to concentrate on crack cocaine markets. Therefore:

... most gang members [Red Gang] will go to like in Scotland, Aberdeen cause you know there's more crack heads up there .... They'll go to Aberdeen, they'll go to Portsmouth, Cardiff (Maxwell).

Maxwell describes how they would travel to other cities for about two weeks to sell crack cocaine: You 'do your stuff, then once you've made your money come back, buy more do the same thing' (see Windle and Briggs forthcoming). This sentence is important: it illustrates how, while part of a gang, Maxwell also bought and sold crack cocaine as an independent entrepreneur.

In addition to independent entrepreneurs such as Maxwell, practitioners identified children being paid $£ 200$ by Red Gang, Rose Boys or GBH to sell crack in towns outside of London (see Windle and Briggs forthcoming). Together the reports by practitioners and Maxwell suggest both individual entrepreneurs and subcontractors commuting from London to set up businesses.

Like Maxwell, several of our participant's narratives presented their involvement in drug dealing as either independent entrepreneurship or as a form of subcontracting on an adhoc basis. These subcontractors and entrepreneurs were not necessarily connected directly with gang structures. For example, some Rose Town-based gang members seemed to buy large quantities of drugs which they sold in smaller quantities to others in the same group who, in turn, sold directly to drug users. One participant detailed how he did not trust fellow gang members because they: 
Windle, J. and Briggs, D. (2015). 'Goin Solo: The Social Organisation of Drug Dealers within a London Gang'. Journal of Youth Studies, 18(9): 1170-1185 Pre-publication copy

... ask you to take some and that they'll pay you back and then they don't pay and you end up fighting them. And then you've got people coming after you for fighting them and stuff like that (Kane).

This statement does not portray a cohesive group with a rigid hierarchy and rules to manage drug market operations. Rather it suggests that interpersonal relationships count more than formal gang rules.

Several participants described drifting in and out of retailing. Richard, for example, explained how he sold cocaine and cannabis occasionally; primarily when his mum fell behind on the rent. While, when asked how 'many times have you been asked to shot [sell drugs] in your life', Kane replied:

I haven't been asked. Like I just think that I need to make money. Save up buy some then flip that [reinvest it] and make double your money

Leo, on the other hand, had been asked to sell cannabis for older boys (aged 16/17) about five times, for which he received half of the profits. He stopped because he was concerned that he might lose the cannabis, for which he would be to liable to pay the full amount:

It's a risk because you can lose it or get it robbed and I see a boy got stabbed because he didn't pay back drugs he lost, like getting put in hospital and that.

This does, however, conflict with information from Jermaine who reported younger people being paid $£ 40 / 50$ out of every $£ 300$ sold. While Andrew, a YOT worker, recalled how one youth he interviewed was paid a small amount of amphetamine for delivering drugs:

I think they used to call him the ASBO kid. Well he used to get kind of bullied a little bit because he always wanted to be in the gang. But they knew that he wouldn't be discreet enough or whatever else as he was a bit slow. So he kind of did the only thing that they would ask him to do every 
Windle, J. and Briggs, D. (2015). 'Goin Solo: The Social Organisation of Drug Dealers within a London Gang'. Journal of Youth Studies, 18(9): 1170-1185 Pre-publication copy

now and that was to just run on his bike with these drugs and I think they kind of like took the piss out of him and he just wanted to be involved. And the award would almost just be a kind of tap on the back by the elder.

The 'ASBO kid' was 'content with friendship or basking in the glow of the power of more charismatic or influential players' (Hobbs 2013, p. 5). These conflicting accounts may suggest that the profit percentage is determined by individual relationships rather than formal gang rules, in a similar way as the more certified are in better positions to dispute instructions from leaders.

The above discussion suggests that drug dealing takes place around a complex network of individuals, some of whom buy larger amounts which they sell wholesale. Others buy from wholesalers to retail to consumers. Some retail small amounts themselves, others retail sufficient amounts to profit from subcontracting their enterprise. This does not rule out the use of coercion (as described by Hales and Hobbs 2010): some relationships may be based upon extortion or force, however, the evidence suggests that if this does occur it is individually driven dynamic rather than collectively managed. This may also account for why Kwasi saw Red Gang as providing a protection from robbery, while Leo and Kane identified threats emanating from within Red Gang: different people have different perceptions of the structure and organisation of Red Gang because they have different experiences of the group. In this way - according to the gang members / ex-gang members interviewed - while the gang is composed of a number of drug dealers it is not a drug dealing organisation.

\section{Conclusion}

This paper has documented the dynamics of one street gang, affiliated with three other gangs in a loose coalition. Though limited by various constraints, the paper offers new insights into the way in which some London gangs may be structured and the operation of drug sales. Two main conclusions can be drawn. The first draws from the experiences of the gang members / ex-gang members we interviewed. They suggested that they were not formally recruited into Red Gang nor were they motivated and controlled by bureaucratic gang rules. They were instead motivated and organised by their own economic and social self-interest. Red Gang was a loose network of individual actors who drifted into the gang through normal social processes. While there seems to have been some leadership, the level of authority some 
Windle, J. and Briggs, D. (2015). 'Goin Solo: The Social Organisation of Drug Dealers within a London Gang'. Journal of Youth Studies, 18(9): 1170-1185 Pre-publication copy

individuals may have had over others is likely to be dependent upon individual relationships, rather than formal gang structures and rules. Red Gang is composed of a number of people who deal/run drugs. This does not make it a drug-dealing organization. The gang is built of individuals with different motivations, personalities and work ethics. Some are skilled entrepreneurs, some are employers, and some are sub-contractors. Some are respected by other gang members while others have little respect from their peers.

The second main conclusion is that there was a significant divergence of perspective from the young people and practitioners who participated in the study. This loose network of individual actors with minimal rules is how the young people described themselves. The practitioners painted a very different picture: one of a more rigid, hierarchical organisation with formal rules and exploitative recruitment processes. They tended to discuss gangs using militaristic language which implied sophisticated organisation.

It has been suggested that we can view gang structures on a continuum from the less organised to the more organised and, the more recreational to the more entrepreneurial. The young people who constituted Red Gang described a less organised social network composed of individuals ranging in their entrepreneurial skill and motivation. Practitioners conversely describe a more organised entrepreneurial gang. This divergence of perspective has been identified elsewhere by Scott Decker and Kimberley Kempf-Leonard (1991). Explanations for this divergence could include the influence of the media (Decker and Kempf-Leonard 1991) and political rhetoric, such as the statement by David Cameron in the quote at the start of this paper or contained in the British Governments street gang strategy (HM Government 2011). It could also be that practitioners may project onto the gang their own experiences of working within hierarchical, bureaucratic and well organised institutions (Hallsworth and Young 2008). The practitioners we spoke to provided thoughtful answers and appeared wellinformed and well-intentioned. As such, the reason for this divergence in perception represents a gap in the knowledge base and is an issue worthy of further investigation.

Understanding the problem is the first step towards developing and implementing effective responses to street gangs and drug markets (Decker and Kempf-Leonard 1991; see Laycock and Tilley 1995). That those participating in, and responding to, street gangs viewed organisational structure and the groups role in drug dealing differently presents significant challenges to policies and practice. This suggests that much more needs to be done in the UK 
Windle, J. and Briggs, D. (2015). 'Goin Solo: The Social Organisation of Drug Dealers within a London Gang'. Journal of Youth Studies, 18(9): 1170-1185 Pre-publication copy

to develop our understanding of street gangs and, the relationship between street gangs and drug markets.

In addition to the divergence between gang members / ex-gangs members and practitioners, some of the young people we spoke to offered somewhat contradictory answers on how Red Gang, and drug dealing, was organised. Kane, Kwasi and Leo, for example, offer two different perspectives on the role of the gang in protecting members from robbery. Kwasi felt the gang provided a protective function. Kane and Leo felt that gang members could not be trusted. We suspect that this is because each gang member has a very different experience of the gang. Kwasi was confident and tough. This may have motivated the group to rally round him. This again suggests that, in Red Gang, interpersonal relationships counted more than formal gang rules. That different people have different experiences of the group is an additional important consideration for those attempting to understand gangs and formulating gang policy and practice.

Earlier studies of London street gangs found hierarchically structured entrepreneurial gangs (Densley 2012; Pitts 2007, 2008). We accept that there is a diversity of gangs and drug markets (see Fagan 1989; Weisel 2002), and gangs and the markets within which they operate are in a constant state of flux. This diversity is the product of individual personalities, the social and built environments the gangs operate within, the state response to gangs and the products they sell. We are not, therefore, trying to generalise our findings out to London or the UK as a whole. Rather we have provided an in-depth case study of a single London gang, connected to three other gangs in a loose coalition. It is hoped that our case study will be compared to other case studies. Such an approach will help inform researchers, practitioners and policy makers of the diversity of gangs within London and the UK. This said, we suspect that some gangs which appear to be hierarchically structured at first glance may, on closer inspection, be looser networks of individuals and cliques; although this may well depend upon who you ask.

\section{References}

Akhtar, S. and South, N. 2000. "Hidden from Heroin's History: Heroin Use and Dealing Within an English Asian Community - A Case Study.” In Illegal Drug Markets: From Research to Policy edited by, M. Hough and M. Natarajan. New York: Criminal Justice Press. 
Windle, J. and Briggs, D. (2015). 'Goin Solo: The Social Organisation of Drug Dealers within a London Gang'. Journal of Youth Studies, 18(9): 1170-1185 Pre-publication copy

Aldridge, J. and Medina, J. 2008. Youth Gangs in an English City: Social Exclusion, Drugs and Violence: Full Research Report ESRC End of Award Report, RES-000-23-0615.

Swindon: ESRC.

Alleyne, E. and Wood, J.L. 2010. "Gang Involvement: Psychological and Behavioural Characteristics of Gangs Members, Peripheral Youth and Non-Gang Youth." Aggressive Behaviour, 36(6): 423-436.

Briggs, D. 2008. “Robbery Careers: Desistance Attempts.” Safer Communities, 7(3): 37-34.

Briggs, D. 2010. “The World is Out to Get Me, Bruv: Life After School Exclusion." Safer Communities, 9(2): 9-19.

Bourgois, P. 1995. In Search of Respect: Selling Crack in El Barrio. Cambridge: Cambridge University Press.

Bullock, K. and Tilley, N. 2002. Shootings, Gangs and Violent Incidents in Manchester: Developing a Crime Reduction Strategy. Crime Reduction Research Series Paper 13. London: Home Office.

Bullock, K. and Tilley, N. 2008. "Understanding and Tackling Gang Violence.” Crime Prevention and Community Safety, 10(1): 36-47.

Centre for Social Justice, 2009. Dyeing to Belong, available online at: www.centreforsocialjustice.org.uk

Curry, G.D., Decker, S.H. and Pyrooz, D.C. 2013. Confronting Gangs: Crime and Community. Oxford: Oxford University Press.

Curtis, R., and Wendel, T. 2000. "Toward the Development of a Typology of Illegal Drug Markets." In Illegal Drug Markets: From Research to Prevention edited by M. Natarajan and M. Hough. New York: Criminal Justice Press.

Davies, A. 1998. "'Youth Gangs, Masculinity and Violence in Late Victorian Manchester and Salford." Journal of Social History 32 (2): 349-69.

Decker, S.H. 2000. "Legitimating Drug Sales: A Note on the Impact of Gang Membership and Drug Sales on the Use of Illicit Drugs.” Justice Quarterly, 17(2): 394-410.

Decker, S.H., Bynum, T. and Weisel, D. 1998. "A Tale of Two Cities: Gangs as Organized Crime Groups.” Justice Quarterly, 15(3): 395-426.

Decker, S.H. and Curry, G.D. 2002. "Gangs, Gang Homicides, and Gang Loyalty: Organized Crimes or Disorganized Criminals.” Journal of Criminal Justice, 30(4): 343-352.

Decker, S. and Kempf-Leonard, K. 1991. "Constructing Gangs: The Social Definition of Youth Activities.” Criminal Justice Policy Review, 5(4): 271-291. 
Windle, J. and Briggs, D. (2015). 'Goin Solo: The Social Organisation of Drug Dealers within a London Gang'. Journal of Youth Studies, 18(9): 1170-1185 Pre-publication copy

Decker, S. and Von Winkle, B. 1995. “'Slinging Dope': The Role of Gangs and Gang Members in Drug Sales.” Justice Quarterly, 11(4): 1001-1022.

Densley, J.A. 2012. "Its Gang Life, but Not as we Know It: The Evolution of Gang Business." online advanced access Crime and Delinquency, doi:10.1177/0011128712437912

Densley, J.A. and Stevens, A., (2014). “'We'll Show You Gang': The Subterranean Structuration of Gang Life in London." Criminology and Criminal Justice, 15 (1): 102-120.

Durán, R.J. 2010. "Gang Organization: Slangin', Gang Bangin', and Dividn' by Generation'." Latino Studies, 8(3): 373-398.

Esbensen, F. A. and Huizinga, D. 1993. "Gangs, Drugs, and Delinquency in a Survey of Urban Youth." Criminology, 31(4): 565-587.

Esbensen, F. and Tusinski, K.E. 2007. "Youth Gangs in the Print Media." Journal of Criminal Justice and Popular Culture, 14 (1): 21-39.

Fagan, J. 1989. "The Social Organization of Drug Use and Drug Dealing Among Urban Gangs." Criminology, 27(4): 633-669.

Fairlie, R.W. 2002. "Drug Dealing and Legitimate Self-Employment." Journal of Labor Economics, 20(3): 538-537.

Fox, K.A. and Lane, J. 2010. "Perceptions of Gangs Amongst Prosecutors in an Emerging Gang City." Journal of Criminal Justice, 38(4): 595-603.

Gambetta, D. 1993. The Sicilian Mafia. Harvard University Press, London.

Hales, G. and Hobbs, D. 2010. "Drug Markets in the Community: A London Borough Case Study." Trends in Organised Crime, 13(1): 13-30.

Hallsworth, S. and Young, T. 2008. "Gang Talk and Gang Talkers: A Critique." Crime, Media, Culture, 4(2): 175-195.

Harding, S 2014. The Street Casino: Survival in Violent Street Gangs. Bristol: Policy Press. HM Government. 2011. Ending Gang and Youth Violence. London: HM Government. Hobbs, D., 2013. Lush Life: Constructing Organized Crime in the UK. Oxford: Oxford University Press.

Jacobs, B.A. and R. Wright. 2008. "Moralistic Street Robbery." Crime and Delinquency 54 (4): 511-531.

Joseph, I. and Gunter, A. 2011. What's a Gang and what's Race got to do with it? London: Runnymede Trust. 
Windle, J. and Briggs, D. (2015). 'Goin Solo: The Social Organisation of Drug Dealers within a London Gang'. Journal of Youth Studies, 18(9): 1170-1185 Pre-publication copy

Kenney, M. 2007. From Pablo to Osama: Trafficking and Terrorist Networks, Government Bureaucracies, and Competitive Advantage. Pennsylvania: Penn State University Press.

Klein, M. 1995. The American street Gang: Its Nature, Prevalence, and Control. Oxford: Oxford University Press.

Klein, M., Weerman, F.M. and Thornberry, T.P. 2006. "Street Gang Violence in Europe, European Journal of Criminology.” 3(4): 1477-3708.

Lampe, K. and Johansen, P., 2004. Criminal Networks and Trust. On the Importance of Expectations of Loyal Behaviour in Criminal Relations. In Organised Crime, Trafficking, Drugs: Selected Papers Presented at the Annual Conference of the European Society of Criminology, edited by S. Nevala and K. Aromaa. New York: Criminal Justice Press.

Laycock, G. and Tilley, N. 1995. "Implementing Crime Prevention." In Crime and Justice edited by M. Tonry and D. Farrington. Chicago: University of Chicago Press.

Lo, T.W. 2011. "Triadization of Youth Gangs in Hong Kong.” British Journal of Criminology 52(3): 556-576.

London Poverty Profile, 2013. Poverty Indicators. Available online: http://www.londonspovertyprofile.org.uk/indicators/

Lupton, R., Wilson, A., May, T., Warburton, H. and Turnbull, P.J. 2002. A Rock and a Hard Place: Drug Markets in Deprived Neighbourhoods. Home Office Research Study 240. London: Home Office.

Mares, D. 2001. "Gangsters or Lager Louts? Working Class Street Gangs in Manchester.” In The Eurogang Paradox: Street Gangs and Youth Groups in the US and Europe, edited by M.W. Klein, J.H.J. Kerner, C.L. Maxson, and E.G.M. Weitekampp. Dordrecht: Kluwer.

March, J. and Simon, H. (1993) Organizations. Oxford: Blackwell.

Marshall, B., Webb, B. and Tilley, N. 2005. "Rationalisation of Current Research on Guns, Gangs and Other Weapons." London: Jill Dando Institute of Crime Science.

May, T. and Hough, M. 2004. "Drug Markets and Distribution Systems." Addiction Research \& Theory, 12(6): 549-563.

May, T., Duffy, M., Few, B. and Hough, M. 2005, Understanding Drug Selling in Communities: Insider or Outsider Trading? Joseph Rowntree Foundation.

Mieczowski, T. 1986. "Geeking Up and Throwing Down: Heroin Street Life in Detroit." Criminology, 24(4): 645-665.

Morselli, C. 2001. "Structuring Mr. Nice: Entrepreneurial Opportunities and Brokerage Positioning in the Cannabis Trade." Crime, Law and Social Change, 35(3): 203-244 
Windle, J. and Briggs, D. (2015). 'Goin Solo: The Social Organisation of Drug Dealers within a London Gang'. Journal of Youth Studies, 18(9): 1170-1185 Pre-publication copy

Office of National Statistics, 2013. Neighbourhood Statistics. Available online: http://www.ons.gov.uk/ons/index.html

Padilla, F.M. 1996. The Gang as an American Enterprise. New Jersey: Rutgers University Press.

Papachristos, A.V. 2006. "Social Network Analysis and Gang Research: Theory and Method." In Studying Youth Gangs edited by J.E. Short and L.A. Hughes. Oxford: AltaMira Press.

Powell, W.W. 1990. "Neither Market nor Hierarchy: Network Forms of Organization." In Research in Organizational Behaviour edited by B. Staw and L.L. Cummings. Middlesex: JAI Press.

Pitts, J. 2007. Reluctant Gangsters: Youth Gangs in Waltham Forest, London: Waltham Forest Local Authority.

Pitts, J. 2008. Reluctant Gangsters: The Changing Face of Youth Crime. Devon: Willan Ralphs, R., Medina, J. and Aldridge, J. 2009. "Who Needs Enemies with Friends Like These? The Importance of Place for Young People Living in Known Gang Areas." Journal of Youth Studies, 12(5): 483-500.

Reuter, P. 1983. Disorganized Crime: The Economics of the Visible Hand. Cambridge: MIT Press.

Ruble, N.M. and Turner W.T. 2000. "A Systematic Analysis of Dynamics and Organisation of Urban Street Gangs.” The American Journal of Family Therapy, 28(2): 117-132.

Sánchez-Jankowski, M. 1991. Islands in the Street: Gangs and the American Urban Society. London: University of California Press.

Sánchez-Jankowski, M. 2003. "Gangs and Social Change.” Theoretical Criminology, 7(2): 191-216.

Smithson, H., Monchuk, L. and Armitage, R. 2012. "Gang Member: Who Says? Definitional and Structural Issues." In Youth Gangs an International Perspective: Tales from the Eurogang Program of Research edited by F.A. Esbensen and C.L. Maxson. London: Springer.

Skolnick, J.H., Correl, T., Navarro, E. and Rabb, R. 1990. “The Social Structure of Street Dealing." American Journal of Police, 9(1): 1-41.

Valdez, A. and Sifaneck, S.J. 2004. "Getting High and Getting By: Dimensions of Drug Selling Behaviours Among American Mexican Gang Members in South Texas." Journal of Research in Crime and Delinquency, 41(1): 82-105. 
Windle, J. and Briggs, D. (2015). 'Goin Solo: The Social Organisation of Drug Dealers within a London Gang'. Journal of Youth Studies, 18(9): 1170-1185 Pre-publication copy

Venkatesh, S.A. 1997. "The Social Organization of Street Gang Activity in an Urban Ghetto.” American Journal of Sociology, 103(1): 82-111.

Venkatesh, S.A. and Levitt, S.D. 2000. "'Are We a Family or a Business?' History and Disjuncture in the American Street Gang.” Theory and Society, 29(4): 427-462.

Weerman, F.M., Maxson, C.L., Esbensen, F.A., Aldridge, J., Medina, J. and van Gemert, F. 2009. Eurogang Programme Manual. Accessed online at:

https://www.escholar.manchester.ac.uk/api/datastream?publicationPid=uk-ac-manscw:58536\&datastreamId=FULL-TEXT.PDF

Weisel, D.L. 2002. "The Evolution of the Street Gang: An Examination of Form and Variation." In Responding to Gangs: Evaluation and Research edited by W.L. Reed and S.H. Decker. Washington: National Institute of Justice.

Windle, J. 2013. "Tuckers Firm: A Case Study of British Organised Crime." Trends in Organised Crime, 16(4): 382-396.

Windle, J. and Farrell, G. 2012. "Popping the Balloon Effect: Assessing Drug Law Enforcement in Terms of Displacement, Diffusion, and the Containment Hypothesis." Substance Use \& Misuse, 47(8-9): 868-876.

Winlow, S. 2001. Badfellas: Crime, Tradition and New Masculinities. Oxford, Berg.

Wintour, P., Dodd, V., Carrell, S. and Gumbel, A. 2011. "UK Riots: Cameron Looks for Lessons from LA to Tackle Home-grown Gangs." The Guardian, $11^{\text {th }}$ August, 2011.

Wood, J. and Alleyne, E. 2010. "Street Gang Theory and Research: Where are we now and where do we go from here?" Aggression and Violent Behaviour, 15(2): 100-111.

Windle, J. and Briggs, D. forthcoming. “'It's Like Working Away for Two Weeks': The Harms Associated with Young Drug Dealers Commuting from a Saturated London Drug Market." Accepted for publication in Crime Prevention and Community Safety. 